Infect Dis Obstet Gynecol 2003;11:209-216

\title{
Improving appropriate use of antifungal medications: the role of an over-the-counter vaginal $\mathrm{pH}$ self-test device
}

\author{
Subir Roy ${ }^{1}$, James C. Caillouette ${ }^{2}$, Joel S. Faden ${ }^{3}$, Tapon Roy \\ and Diana E. Ramos ${ }^{5}$ \\ ${ }^{1}$ Professor Obstetrics and Gynecology, Keck School of Medicine of the University of Southern California, \\ Women's and Children's Hospital, Los Angeles, CA \\ ${ }^{2}$ Private Practice Obstetrics and Gynecology (Retired), Pasadena, $C A$ \\ ${ }^{3} \mathrm{FD} A$ Regulatory Consultant, Washington, DC \\ ${ }^{4}$ Statistical Consultant, Bethel, CT \\ ${ }^{5}$ Private Practice Obstetrics and Gynecology, Monterey Park, CA
}

\begin{abstract}
Objectives: To determine whether patients can understand and use the vaginal $\mathrm{pH}$ device in the diagnosis of vaginitis. To compare whether vaginal $\mathrm{pH}$ readings determined by patients and healthcare providers are similar. To determine whether vaginal $\mathrm{pH}$ can reduce inappropriate over-the-counter (OTC) antifungal medication use and improve the correct diagnosis of vaginitis.

Methods: One hundred and fifty-one women indicated their belief about the cause of their vaginal infection, read the instructions of the vaginal $\mathrm{pH}$ device package insert, used the device and interpreted the findings. The patient interpretations were compared with results obtained by healthcare providers, blinded to patient findings.

Results: Over $96 \%$ of patients stated that they could easily read the instructions, use the vaginal $\mathrm{pH}$ device and interpret the readings. They obtained the same readings as healthcare professionals (Kappa $=0.9)$. Restricting the use of OTC antifungal medications to those individuals with vaginitis symptoms and vaginal $\mathrm{pH} \leq 4.5$ significantly reduced inappropriate use by approximately $50 \%$, Fisher's exact test, $p$-value $=0.018$. Conversely, seeking healthcare provider assessment with vaginal $\mathrm{pH}>4.5$, leads to correct diagnosis of vaginitis.

Conclusions: The vaginal $\mathrm{pH}$ device can be used as an OTC diagnostic tool by consumers when a vaginal infection is suspected. Vaginal pH readings would direct patients whether to purchase an antifungal medication or seek professional diagnosis from a healthcare provider. Understanding and use of this vaginal $\mathrm{pH}$ device could reduce inappropriate use of OTC antifungal medications by approximately $50 \%$ and improve the correct diagnosis of vaginitis.
\end{abstract}

Key words: Aid; SelF-Diagnosis; VAGinitis

Dr. Caillouette is founder and principal owner of FemTek LLC and Dr. Faden has a financial interest in FemTek LLC, which holds the intellectual property rights to the vaginal $\mathrm{pH}$ device used in this study. This study was funded by FemTek LLC.

Correspondence to: Subir Roy MD, Department of Obstetrics and Gynecology, Keck School of Medicine of the University of Southern California, Women's and Children's Hospital, 1240 N. Mission Road, Room L1022, Los Angeles, CA 90033, USA. Email: subirro@usc.edu 
Since the United States Food and Drug Administration (FDA) allowance of over-the-counter (OTC) vaginal antifungal medication in $1990^{1}$, there have been numerous reports of inappropriate use of such therapy ${ }^{2-4}$. These observations are not surprising because of the high likelihood of bacterial infections responsible for vaginitis. Bacterial infections account for $11-64 \%$ of vaginal infections in symptomatic non-pregnant patients ${ }^{5}$ while trichomonal infections account for $5-25 \%$ of family planning or gynecology clinic visits and up to $32 \%$ in STD clinics ${ }^{6}$. Physician or healthcare provider use of vaginal $\mathrm{pH}$ testing has been shown to be of utility in diagnosing the causes of vaginitis $^{7-9}$. We have shown that subjects can read the package insert and understand the role of a vaginal $\mathrm{pH}$ device $^{10}$. It is our suggestion that patients can use the vaginal $\mathrm{pH}$ self-test device (Figure 1) as a screening tool, leading to less inappropriate use of antifungal medications and more appropriate use of healthcare provider examinations.

In order to understand better the place of vaginal $\mathrm{pH}$ testing some historical facts are reviewed. $\mathrm{pH}$ paper has been described to test vaginal $\mathrm{pH}$ in an American medical textbook published as early as $1950^{11}$. The early textbook specifically recommended Nitrazine ${ }^{\circledR}$ (phenaphthazine) $\mathrm{pH}$ paper for vaginal $\mathrm{pH}$ testing. The same Nitrazine $\mathrm{pH}$ paper is used for the vaginal $\mathrm{pH}$ self-test device.

Prior to the availability of the vaginal $\mathrm{pH}$ device $^{12}$, it was the practice of physicians to press a strip of $\mathrm{pH}$ paper against the vaginal wall while holding it with either the fingers or a hemostat or to place it in the secretions from the vaginal pool collected in the posterior fornix ${ }^{6}$. The latter practice is not recommended because of contamination with cervical mucus, blood or semen which may result in an incorrect vaginal $\mathrm{pH}$ reading ${ }^{6}$ (generally greater than 6.0 ). The vaginal $\mathrm{pH}$ device makes it convenient for the physician or patient to obtain a vaginal $\mathrm{pH}$ reading from the lateral outer third of the vagina by mounting the paper on the end of a probe, allowing for a less cumbersome procedure and a correct reading.

Secretions from the normal vaginal wall (outer third) of a reproductive-age female are acidic, in the $\mathrm{pH}$ range of $3.8-4.5^{13}$. Vaginal homeostasis is maintained by interrelationships among the endogenous microflora, metabolic products of the microflora and estrogen levels ${ }^{13,14}$. Studies clearly indicate that estrogen is responsible for proliferating surface vaginal epithelium ${ }^{15,16}$. In response to estrogen, the glycogen content within the vaginal cells is increased and released into the vaginal lumen ${ }^{17}$, supporting the growth of various strains of $\mathrm{H}_{2} \mathrm{O}_{2}$ - and lactic acid-producing lactobacillae, that are critical for producing an acidic $\mathrm{pH}$ and maintaining vaginal health ${ }^{14}$. The resulting healthy vaginal microflora is made up of numerous microorganisms including grampositive and gram-negative aerobic, facultative and obligate anaerobic bacteria ${ }^{14,18}$.

An elevated vaginal $\mathrm{pH}$ level (greater than 4.5, considered a positive finding) may indicate various

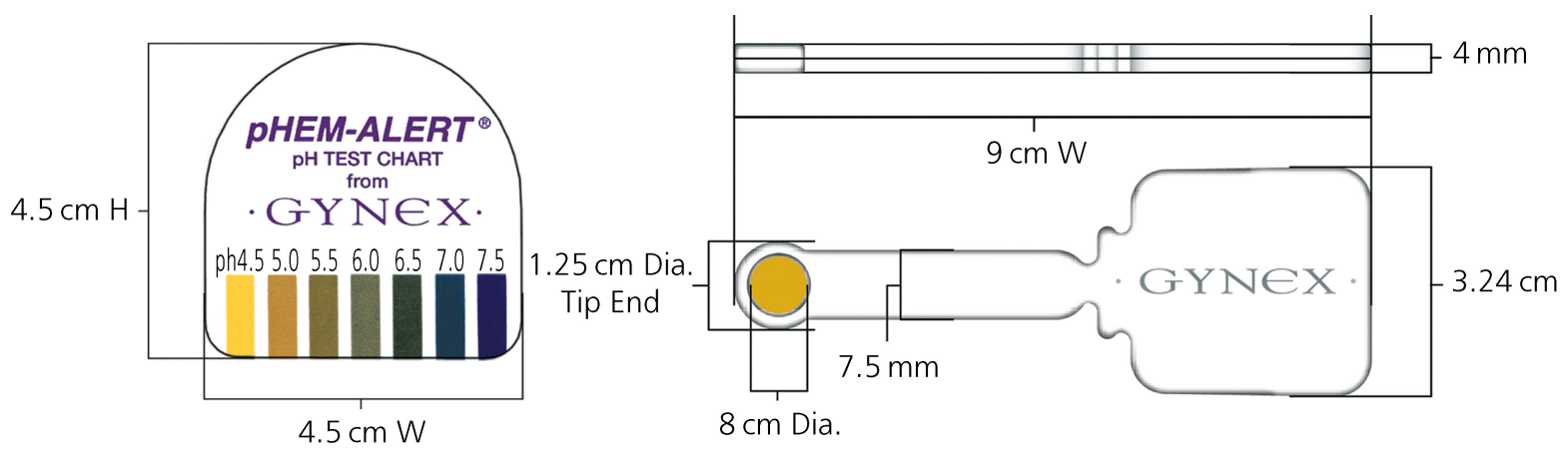

Distributed by GYNEX, 2719 152nd Ave. NE, Redmond, WA 98052.

Figure I The OTC version of the $\mathrm{pH}$ self-test device is identical to the professional/prescription version, except for the package insert, which has been modified specifically to address the needs of the lay user. Both versions are comprised of a plastic probe with $\mathrm{pH}$ paper on one end, a color chart and a package insert. The probe and color chart are illustrated above

$210 \bullet$ INFECTIOUS DISEASES IN OBSTETRICS AND GYNECOLOGY 
conditions, including bacterial infections such as bacterial vaginosis (BV), Trichomonas vaginalis infections, group B streptocococcus (GBS) or other pathogenic organisms ${ }^{9}$. However, like an elevated temperature, an elevated $\mathrm{pH}$ alone is only presumptive and not diagnostic. A diagnosis of the underlying condition or cause of the elevated $\mathrm{pH}$ should be established by obtaining additional history, performing tests and observing the woman's signs and symptoms.

Although prescribed for vaginal testing decades before, the seminal work establishing the importance of vaginal $\mathrm{pH}$ in the diagnosis of vaginal infections was confirmed by Amsel and co-investigators in the early 1980s. The Amsel criteria remain the cornerstone for differential diagnosis of $\mathrm{BV}$ today ${ }^{7}$, with vaginal $\mathrm{pH}$ alone providing the greatest sensitivity of the four clinical signs, but the lowest specificity ${ }^{19}$. Many clinicians today determine vaginal $\mathrm{pH}$ routinely as part of well-woman examinations and as part of the diagnostic process for patients presenting with symptoms of vaginitis ${ }^{20,21}$.

This study was conducted to determine whether patients could understand and use a vaginal $\mathrm{pH}$ device and interpret test results compared with those made by a healthcare provider, as an aid in the diagnosis of vaginitis. Additionally, could appropriate use and interpretation of a vaginal $\mathrm{pH}$ device reduce the numbers of individuals inappropriately using OTC antifungal medication and lead to correct diagnoses of vaginitis?

\section{SUBJECTS AND METHODS}

The study was conducted under the oversight of the IRB Company, Camino de los Mares, CA. Three investigational sites participated in the study: one private practice in North Dakota, one private practice in California and one health clinic in California. These individuals are listed in the acknowledgement section. The patients selected for study were of varied background, educational levels and ages, who were target users (symptomatic patients) and normal controls (asymptomatic patients). As women presented at the participating centers, they were screened to see if they met the inclusion or exclusion criteria. Women who qualified for the study were asked to participate and those who agreed signed informed consents.

The inclusion criteria, for symptomatic women, included vaginal signs or symptoms such as itching, burning, unpleasant odor, unusual discharge and that they have regular menstrual periods. The inclusion criteria for women without symptoms, stipulated that they have regular menstrual periods and be visiting the clinic for routine examination for a non-vaginally related matter. Patients were excluded if they were not mentally or physically capable of reading the instructions and/or performing the test. They were also excluded if they had douched or used contraceptive creams or gels within the last 24 hours; had unprotected sexual intercourse within the last 24 hours; were currently menstruating or the last menstrual period had not been over for 5 days; or were currently pregnant.

Each participant was taken to an examination room and provided a vaginal $\mathrm{pH}$ self-test device, the package insert and a patient questionnaire. The patient was then asked to read the package insert, perform the test and complete the questionnaire after performing the test in privacy. Completed questionnaires were immediately given to the study coordinator who kept the results blinded from the patient's healthcare provider (physician or nurse practitioner).

After the patient had finished, the healthcare provider performed a vaginal $\mathrm{pH}$ test using the vaginal $\mathrm{pH}$ device. A medical examination appropriate to the nature of the patient visit, including microscopy or culture when appropriate, was then carried out. The healthcare provider recorded the test result and completed the study questionnaire without asking the patient any questions regarding her test, its result or her answers to the

Table I Distribution of patients by investigational site and presenting condition

\begin{tabular}{lccc}
\hline \multirow{2}{*}{$\begin{array}{l}\text { Investigational } \\
\text { site }\end{array}$} & \multicolumn{2}{c}{ Condition } & \\
\cline { 2 - 3 } & Normal & Symptomatic & Total \\
\hline 1 & 11 & 38 & 49 \\
2 & 10 & 40 & 50 \\
3 & 12 & 40 & 52 \\
Total & 33 & 118 & 151 \\
\hline
\end{tabular}


questions. The healthcare provider was asked to distinguish between yeast, bacteria or other, in the same manner as we had asked the patients who were not expected to know or diagnose bacterial vaginosis (BV). For practical purposes a diagnosis of 'bacteria' is consistent with BV.

The test results were analyzed using standard statistical methods, including the Fisher's exact test (FET), while the exact permutational version of the Kappa statistic was performed for the extent of agreement between the results of the test when used by patients and healthcare providers

Table 2 Demographic characteristics of patients

\begin{tabular}{lcc}
\hline $\begin{array}{l}\text { Demographic } \\
\text { characteristics }\end{array}$ & $\begin{array}{c}\text { Value/number } \\
\text { of patients }\end{array}$ & $\begin{array}{c}\text { Percentage of } \\
\text { patients }\end{array}$ \\
\hline Age, years & 34.1 & \\
Average $(n=149)$ & 17 & \\
Minimum & 73 & \\
Maximum & 2 & \\
No response given & & \\
Ethnicity & 59 & 39 \\
Caucasian & 5 & 3 \\
African American & 80 & 53 \\
Hispanic & 2 & 1 \\
Asian American & 1 & 1 \\
Other & 4 & 3 \\
No response given & & \\
Years of education & & 58 \\
$0-12$ (actual range) & 87 & 29 \\
I3-16 & 44 & 11 \\
> 16 (graduate) & 3 & \\
No response given & 17 & \\
\hline
\end{tabular}

using SAS Version 8.01 PROC FREQ ${ }^{22}$ and Proc-StatXact $4^{23}$ for SAS.

\section{RESULTS}

The distribution of patients by site and presenting condition is provided in Table 1. One hundred and fifty-one women were enrolled in this study. Thirty-three of the 151 women (22\%) were normal (asymptomatic) and 118 (78\%) were symptomatic. Of the 118 symptomatic patients, 96 were premenopausal, not pregnant, and with a uterus in situ. The healthcare provider did not provide a final diagnosis in eight, leaving 88 symptomatic premenopausal patients for whom patient and healthcare diagnoses were available for analysis. Because the assessment of the product's ease of use or the readability of the instructions for use are not influenced by exclusion criteria, the entire population of enrolled patients was used in selected analyses.

The demographics of the enrolled patients are provided in Table 2 . The women ranged in age from 17 to 73 years old (average 34.1). The study included women with a diversity of ethnic backgrounds. The educational backgrounds of the women were also diverse ranging from 0 years of formal education to graduate school.

The concordance (represented by a Kappa statistic) between the vaginal $\mathrm{pH}$ recorded by the patient and that recorded by the healthcare provider were evaluated separately for all patients and premenopausal patients. The findings were examined considering both the $\mathrm{pH}$ readings as discrete values $(4.5,5.0,5.5,6.0,6.5,7.0,7.5)$ :

Table 3 Initial patients' self-diagnoses versus healthcare providers' diagnoses

\begin{tabular}{|c|c|c|c|c|c|c|}
\hline \multirow[b]{2}{*}{$\begin{array}{l}\text { Patients' initial } \\
\text { self-diagnoses }\end{array}$} & \multicolumn{6}{|c|}{ Healthcare providers' diagnoses } \\
\hline & Yeast & $\begin{array}{l}\text { Bacteria/ } \\
\text { trichomonas }\end{array}$ & Normal & $\begin{array}{l}\text { No conclusion } \\
\text { or no response }\end{array}$ & Total & Subtotal* \\
\hline Yeast & 22 & 13 & 16 & 3 & 54 & 51 \\
\hline Bacteria & 2 & 3 & 1 & 0 & 6 & 6 \\
\hline Yeast and bacteria & I & I & 0 & 0 & 2 & 2 \\
\hline Other & 0 & I & 10 & 3 & 14 & 11 \\
\hline No response given & 3 & 3 & 12 & 2 & 20 & 18 \\
\hline Total & 28 & 21 & 39 & 8 & 96 & 88 \\
\hline
\end{tabular}

*The patients for whom the healthcare provider rendered a diagnosis of vaginitis 
Kappa for all, 0.891 and for premenopausal, 0.898 and as binary values based around the cut-off of 4.5 (dichomotous: $\leq 4.5$ and $>4.5$ ): Kappa for all, 0.870 and for premenopausal, 0.880. The findings demonstrate a high degree of concordance (generally considered 0.8 to 1.0 ) for all four analyses.

Of the 88 symptomatic premenopausal women who had a diagnosis documented by the healthcare provider, 32\% (28/88) were diagnosed with yeast, $23 \%(21 / 88)$ with bacteria or trichomonas and $45 \%$ (39/88) were found to be normal (Table 3).

At the time of their enrollment in the study, 51 of the 88 symptomatic premenopausal women believed they had a yeast infection at entry into the study before using the vaginal $\mathrm{pH}$ device (58\%). Of these 51 women, $43 \%(22 / 51)$ were diagnosed as having a yeast infection, 26\% (13/51) as having a bacterial or trichomonas infection and $31 \%$ (16/51) were diagnosed as normal by the healthcare provider examination. Therefore, if all 51 women had self-medicated themselves with OTC antifungal medications, 57\% (29/51) would have been wrong. Of the 29 who would have misused antifungal medication, 45\% (13/29) would have continued to suffer an opportunistic untreated bacterial infection during their course of self-medication.

After performing the vaginal $\mathrm{pH}$ test (Table 4), when the test was less than or equal to $4.5,42 \%$ $(21 / 50)$ thought they had a yeast infection while $76 \%(16 / 21)$ actually had a yeast infection. This represents a significant reduction in misuse of antifungal medications of greater than $50 \%$, from $57 \%(29 / 51)$ to $24 \%(5 / 21)$, FET $=0.018$. Of the five patients without a yeast infection, one $(20 \%)$ would have continued to suffer from an opportunistic bacterial infection. Thus, inappropriate therapy for opportunistic infections would have been reduced from $45 \%(13 / 29)$ to $20 \%$ $(1 / 5)$, FET $=0.38$, a non-significant reduction because of small numbers. When the test was greater than $4.5,13 \%(5 / 38)$ had a yeast infection, as determined by the healthcare provider examination.

In order to determine vaginal $\mathrm{pH}$ test performance, standard definitions were used $(\text { Table } 4)^{24}$. The information contained in Table 5 was re-formulated into a dichotomous form (Table 6), which permitted the calculation of test

Table 4 Test performance definitions ${ }^{24}$

\begin{tabular}{lccc}
\hline & Disease positive $(+)$ & Disease negative $(\rightarrow)$ & Total \\
\hline Test result positive $(+)$ & TP & FP & TP+FP \\
Test result negative $(-)$ & FN & TN & FN+TN \\
Total & TP + FN & FP+TN & All \\
& Sensitivity $=$ TP/(TP+FN) & Specificity $=$ TN/(FP+TN $)$ & \\
\hline
\end{tabular}

$T P$, true positive; $F P$, false positive; $F N$, false negative; $T N$, true negative; positive predictive value $(P P V)=T P /(T P+F P)$; false-positive rate $=(100 \%-P P V)$; negative predictive value $(N P V)=T N / F N+T N)$; false-negative rate $=(100 \%-N P V)$

Table 5 Patient's response after performing vaginal $\mathrm{pH}$ test and healthcare provider's (HCP) diagnosis

\begin{tabular}{|c|c|c|c|c|c|c|c|c|c|}
\hline & \multicolumn{4}{|c|}{$H C P: p H>4.5$} & \multicolumn{4}{|c|}{$H C P: p H \leq 4.5$} & \multirow{2}{*}{$\begin{array}{l}\text { Grand } \\
\text { Total }\end{array}$} \\
\hline & Yeast & $B / T$ & Normal & Total & Yeast & $B / T$ & Normal & Total & \\
\hline \multicolumn{10}{|l|}{$\begin{array}{l}\text { Patient's decision after self-test of } \\
\text { vaginal } \mathrm{pH} \text { device: }\end{array}$} \\
\hline Rx with OTC anti-fungal medications* & 3 & 2 & 4 & 9 & 16 & 1 & 4 & 21 & 30 \\
\hline Contact healthcare provider $(\mathrm{HCP})^{* *}$ & I & 16 & 6 & 23 & 5 & 0 & 16 & 21 & 44 \\
\hline Do nothing粎 & 1 & 2 & 3 & 6 & 2 & 0 & 6 & 8 & 14 \\
\hline Total & 5 & 20 & 13 & 38 & 23 & 1 & 26 & 50 & 88 \\
\hline
\end{tabular}


Table 6 Patient $\mathrm{pH}$ readings versus healthcare providers' diagnoses (dichotomous arrangement)

\begin{tabular}{lccc}
\hline & \multicolumn{2}{c}{ Healthcare providers' diagnoses } & \\
\cline { 2 - 3 } & Bacteria $(B) /$ trichomonas $(T)$ & Yeast or normal & Grand total \\
\hline Patients' pH readings & 20 & 18 & 38 \\
$\mathrm{pH}>4.5$ & $\mathrm{I}$ & 49 & 50 \\
$\mathrm{pH}<4.5$ & 21 & 67 & 88 \\
Total & & & \\
\hline
\end{tabular}

Table 7 Study test performance as a function of various prevalence assumptions and compared with literature estimates

\begin{tabular}{|c|c|c|c|c|c|}
\hline & $\begin{array}{l}\text { Observed results } \\
\text { from this study } \\
\text { (Table 6) }\end{array}$ & \multicolumn{3}{|c|}{ Assuming a true prevalence of the following } & \multirow{2}{*}{$\begin{array}{c}\begin{array}{c}\text { Composit } \\
\text { values from } \\
\text { references 7-9 }\end{array} \\
0.95\end{array}$} \\
\hline Sensitivity & 0.95 & & & & \\
\hline Specificity & 0.73 & & & & 0.61 \\
\hline Prevalence & 0.24 & 0.2 & 0.3 & 0.5 & 0.3 \\
\hline Positive predictive value & 0.53 & 0.47 & 0.6 & 0.78 & 0.51 \\
\hline Negative predictive value & 0.98 & 0.98 & 0.97 & 0.94 & 0.97 \\
\hline
\end{tabular}

performance for vaginal $\mathrm{pH}$ in this study (Table 7). Since the true prevalence of BV in any symptomatic, non-pregnant population is not known (ranging somewhere between 11 and 64\%) , corresponding to a vaginal $\mathrm{pH}>4.5$, the positive predictive value (PPV) and negative predictive value (NPV) were also calculated for three additional assumptions for prevalence $(0.20,0.30$ and 0.50). These assumptions lie within the range of the reported medical literature ${ }^{5}$. The last column of Table 7 lists the test characteristics of the composite of three studies taken from the literature where healthcare providers obtained vaginal $\mathrm{pH}$ and diagnosed the cause of the vaginitis ${ }^{7-9}$.

The patient was given a questionnaire to complete after reading the package insert and performing the test. To the question, 'Was the test easy to use?' 146 patients said 'yes', two said 'no' and three did not respond. Assuming a worst-case approach in which the 'absence of a response' is considered a 'no', 97\% (146/151) of the women found the test easy to use. To the question, 'Were the instructions easy to follow?' 145 patients said 'yes', three said 'no' and three did not respond. Again assuming a worst-case approach, 96\% (146/151) of the women found the instructions easy to follow.

\section{DISCUSSION}

This study demonstrates that the device and labeling are well designed and meet the needs for home testing. Nearly all of the patients found the test easy to use and the instructions easy to follow. A parallel study demonstrated that age, years of education, ethnicity and clinic location did not alter the ability of subjects to read and understand the package insert of the vaginal $\mathrm{pH}$ device $^{10}$. Furthermore, the high degree of concordance $(0.870$ to 0.891$)$ of patients' vaginal $\mathrm{pH}$ readings with those obtained by the healthcare provider suggests that the vaginal $\mathrm{pH}$ device is designed and labeled appropriately.

This study suggests that by restricting antifungal use to symptomatic patients having vaginal $\mathrm{pH} \leq 4.5$, would reduce misuse of antifungals by about $50 \%$. Such misuse and overuse of incorrect treatment by symptomatic women is extensively reported in the medical literature ${ }^{2-4}$. According to a survey of 390 gynecologists conducted by the Institute of Epidemiological Research, an estimated $44 \%$ of patients diagnosed with bacterial vaginosis (BV) had initially treated themselves with OTC antifungal medications for what they had improperly assumed was a yeast 
infection $^{20}$. This observation is amplified by a study of patient self-diagnosis in 111 women across the US, in which $67 \%$ of women who believed they had a yeast infection were found to be incorrect ${ }^{25}$. Because of the improper use of OTC antifungal medications, the vaginal microflora may be altered ${ }^{26}$ and opportunistic infections such as BV may go unchecked and untreated. Vaginitis, in particular BV, has been associated with increased risk of serious obstetric and gynecologic complications and disorders ${ }^{27-31}$.

Since the patient is advised to see her doctor/ healthcare provider when the test is positive ( $\mathrm{pH}>4.5)$, a false-positive test would only cause the symptomatic patient to visit her healthcare provider for proper diagnosis of an abnormal condition. The probability of a false-negative vaginal $\mathrm{pH}$ in a symptomatic patient is relatively low given the specificities reported in the medical literature (and summarized in this document) and supported by the clinical findings reported above. Further, the symptomatic patient who has a negative $(\mathrm{pH} \leq 4.5)$ finding would be in the same position she is today (i.e. she could choose to initiate treatment with an OTC antifungal medication or see her doctor). Since there is no OTC treatment currently available for bacterial and trichomonas infection, the potential gain of reducing the misuse of antifungal medications in the larger number of true-positive and true-negative cases clearly outweighs the risk of a false-negative finding.

It is noteworthy that the test characteristics of the patient self-test of the vaginal $\mathrm{pH}$ device were almost exactly the same as those of the composite of three studies taken from the literature $^{7-9}$ where healthcare providers obtained vaginal $\mathrm{pH}$ and diagnosed the cause of the vaginitis (Table 7). Thus, the test performance characteristics of the vaginal $\mathrm{pH}$ self-test device are reasonable and acceptable as an aid in the diagnosis of vaginitis. The correct use of such a device could lead to a more appropriate use of OTC anti-fungal medications and will encourage a more appropriate utilization of healthcare providers. This leads to a proper diagnoses of vaginitis and improved health for women*.

\section{ACKNOWLEDGEMENTS}

We acknowledge the contributions and support of patients recruited from the following sites by the respective individuals and their staff: (1) Private practice: Wendall.Wall, Jr. MD, 275 South 11th Street, Wahpeton, ND 58075; (2) Peter Benson, MD, 8902 Woodman Avenue, Arleta, CA 91331; (3) Private practice: Diana E. Ramos, MD, 880 S. Atlantic Blvd., Suite 302, Monterey Park, CA 91754.

\section{REFERENCES}

1. Food and Drug Administration (FDA) approval of clotrimazole $1 \%$ cream and $100 \mathrm{mg}$ inserts on November 30, 1990, Ingredients and Dosages Transferred from Rx-to-OTC Status, FDA's Orange Book: Approved Drug Products with Therapeutic Equivalence Evaluations, October 2002

2. Weisberg M, Summers P. Patient self-diagnosis of vulvovaginal candidiasis. Female Patient 1996; 21:60-4

3. Sihvo S, Ahonen R, Mikander H, Hemminki E. Self-medication with vaginal antifungal drugs: physician's experiences and women's utilization patterns. Fam Pract 2000;17:145-9

4. Ferris DG, Nyirjesy P, Sobel JD, Soper D, Pavletic A, Litaker MS. Over-the-counter antifungal drug misuse associated with patientdiagnosed vulvovaginal candidiasis. Obstet Gynecol 2002;99:419-25

5. French JL, McGregor JA. Bacterial vaginosis: history, epidemiology, microbiology, sequelae, diagnosis, and treatment. In: Borchardt KA, Noble MA, eds. Sexually Transmitted Diseases:

*The FDA permitted OTC use of the vaginal pH self-test device in October, 2001 because of the following factors: first, this clinical study demonstrated the validity of the vaginal $\mathrm{pH}$ self-test device. Second, the questions that the FDA raised for an OTC device were answered. Third, the use of the vaginal $\mathrm{pH}$ self-test device is substantially equivalent to the Professional Version already approved for use. 
Epidemiology, Pathology, Diagnosis, and Treatment. Boco Raton: CRC Press, 1997:4-39

6. Rein MF, Muller M. Trichomonas vaginalis and trichomoniasis. In: Holmes KK, Mardh P-A, Sparling PF, Wiesner PJ, Cates, Jr. W, Lemon SM, Stamm WE, eds. Sexually Transmitted Diseases, Second edition, McGraw-Hill, Inc, 1990:481-92

7. Amsel R, Totten PA, Spiegel CA, Chen KCS, Eschenbach DA, Holmes KK. Nonspecific vaginitis. Am J Med 1983;74:14-22

8. Eschenbach DA, Hillier SL, Critchlow C, Stevens C, DeRouen T, Holmes KK. Diagnosis and clinical manifestations of bacterial vaginosis. $A m \mathrm{~J}$ Obstet Gynecol 1988;158:819-28

9. Caillouette JC, Sharp CF, Zimmerman GJ, Roy S. Vaginal $\mathrm{pH}$ as a marker for bacterial pathogens and menopausal status. Am J Obstet Gynecol 1997; 176:1270-7

10. Roy S, Caillouette JC, Faden J, Roy T. The role of an over-the-counter vaginal $\mathrm{pH}$ device package insert: can subjects learn what the device is for and how to use it? (submitted for publication)

11. Eastman NJ, Williams Obstetrics, 19th edition, New York, Appleton-Century-Crofts, Inc, 1950: 389-91

12. Food and Drug Administration's Premarket Notification [Section $510(\mathrm{k})$ ] clearance to commercially distribute the Professional vaginal $\mathrm{pH}$ device, dated May 13,1996

13. Smith KPB. Estrogens and the urogenital tract. Studies on steroid hormone receptors and a clinical study on a new estradiol releasing vaginal ring. Acta Obstet Gynecol Scand 1993;72(Suppl 157):S1-26

14. Boskey ER, Telsch KM, Whaley KJ, Moench TR, Cone RA. Acid production of vaginal flora in vitro is consistent with the rate and extent of vaginal acidification. Infect Immun 1999;67:5170-5

15. Rakoff AE, Feo LG, Goldstein L. The biological characteristics of the normal vagina. Am J Obstet Gynecol 1944;47:467-94

16. Lang W. Vaginal acidity and $\mathrm{pH}$ : a review. Obstet Gynecol Surv 1955;10:546-60

17. Gregoire AT, Kandil O, Ledger WJ. The glycogen content of human vaginal epithelial tissue. Fertil Steril 1971;22:64-8

18. Stahl CE, Hill GB. Microflora of the female genital tract. In: Galask RP, Larsen B, eds. Infectious Diseases in the Female Patient, New York, Inc: Springer-Verlag, 1986:16-42

Received 05/05/03; ACCEPTED 09/25/03
19. Hillier SL, Holmes KK. Bacterial vaginosis. In: Holmes KK, Mardh P-A, Sparling PF, Wiesner PJ, Cates, Jr. W, Lemon SM, Stamm WE, eds. Sexually Transmitted Diseases, Second edition, McGrawHill, Inc, 1990:547-60

20. The Vaginitis Report, National Vaginitis Association, Editor: Richard Sweet, MD, Fall 1996

21. Food and Drug Administration's (FDA) Clinical Chemistry and Clinical Toxicology Devices Panel Meeting December 7, 1999 (convened to discuss home use of vaginal $\mathrm{pH}$ testing) Transcript. Dr. Jane Schwebke, MD, FACP - Associate Professor of Medicine and Epidemiology, Medicine/Infectious Diseases and School of Public Health, University of Alabama at Birmingham, who was asked by FDA to speak as an expert, stated "I confess that I do pH's on all women I see ..."

22. SAS Institute, Inc. Cary, NC, USA, 2000

23. Cytel Software Corp, Cambridge, MA, USA, 2000

24. Galen RS, Gambino SR. Beyond Normality: The Predictive Value and Efficiency of Medical Diagnoses. John Wiley and Sons, Inc, 1975:124

25. Weisberg M, Summers P. Patient self-diagnosis of vulvovaginal candidiasis. Female Patient 1996;21: 60-4

26. Ross RA, Lee M-LT, Onderdonk AB. Effect of Candida albicans infection and clotrimazole treatment on vaginal microflora in vitro. Obstet Gynecol 1995;86:925-30

27. Platz-Christensen JJ, Sundstrom E, Larsson P-G. Bacterial vaginosis and cervical intraepithelial neoplasia. Acta Obstet Gynecol Scand 1994;73: 586-8

28. Cohen CR, Duerr A, Pruithithada N, Rugpao S, Hillier SL, et al. Bacterial vaginosis and HIV seroprevalence among female commercial sex workers in Chiang Mai, Thailand. AIDS 1995; 9:1093-7

29. Hillier SL, Nugent RP, Eschenbach DA, Krohn MA, Gibbs RS, et al. Association between bacterial vaginosis and preterm delivery of low-birthweight infants. N Engl J Med 1995;333:1737-42

30. Schwebke JR, Schulien MB, Zajackowski M. Pilot study to evaluate the appropriate management of patients with coexistent bacterial vaginosis and cervicitis. Infect Dis Obstet Gynecol 1995; 3:119-22

31. Sweet RL. Role of bacterial vaginosis in pelvic inflammatory disease. Clin Infect Dis 195;20 (Suppl 2):S271-5 


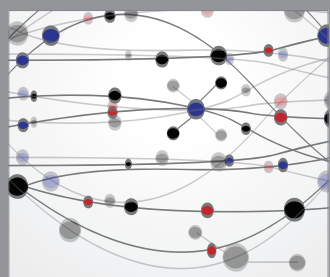

The Scientific World Journal
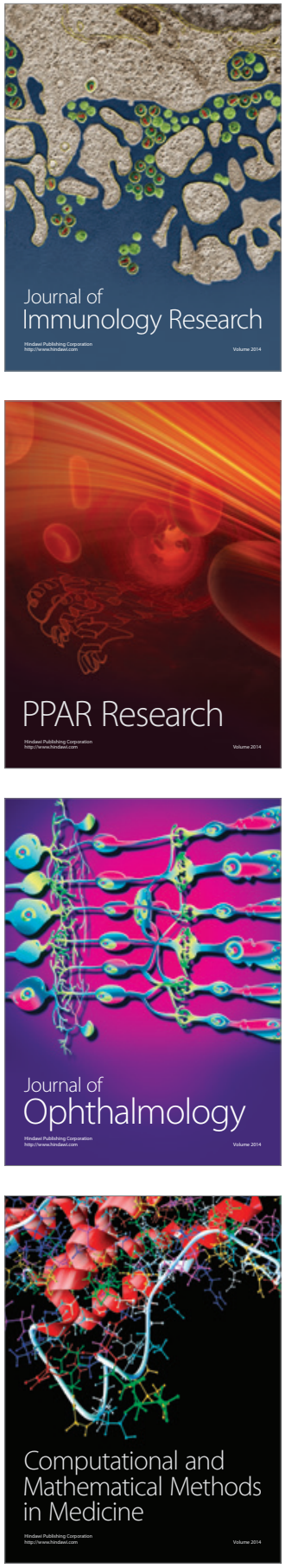

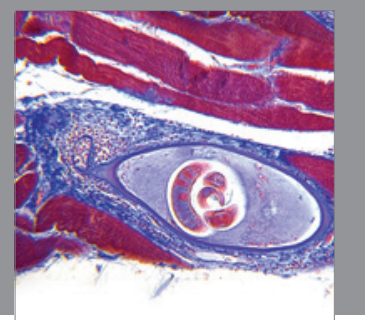

Gastroenterology

Research and Practice
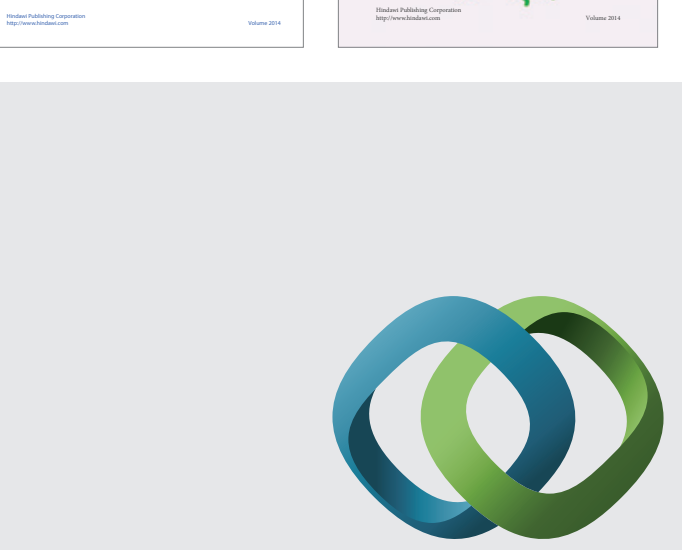

\section{Hindawi}

Submit your manuscripts at

http://www.hindawi.com
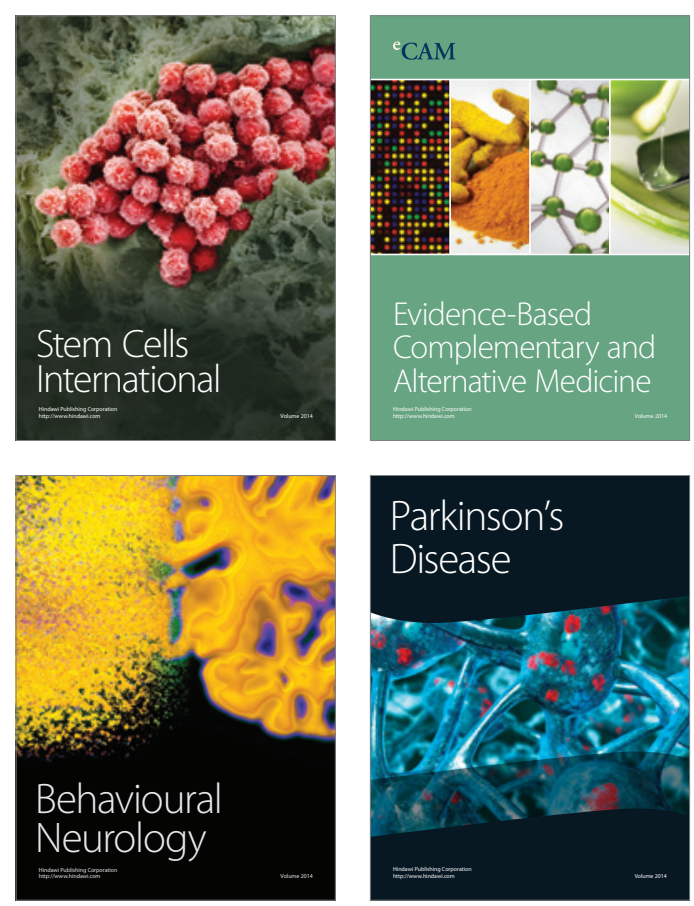

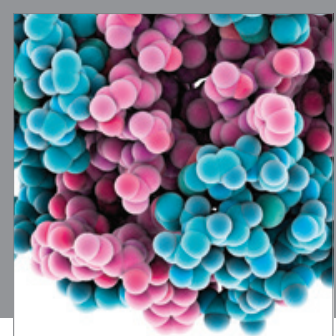

Journal of
Diabetes Research

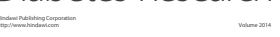

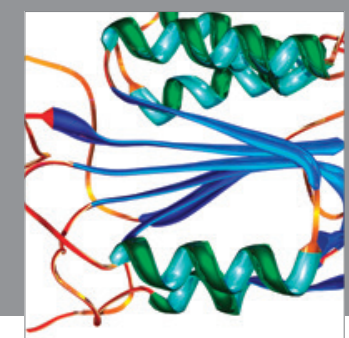

Disease Markers
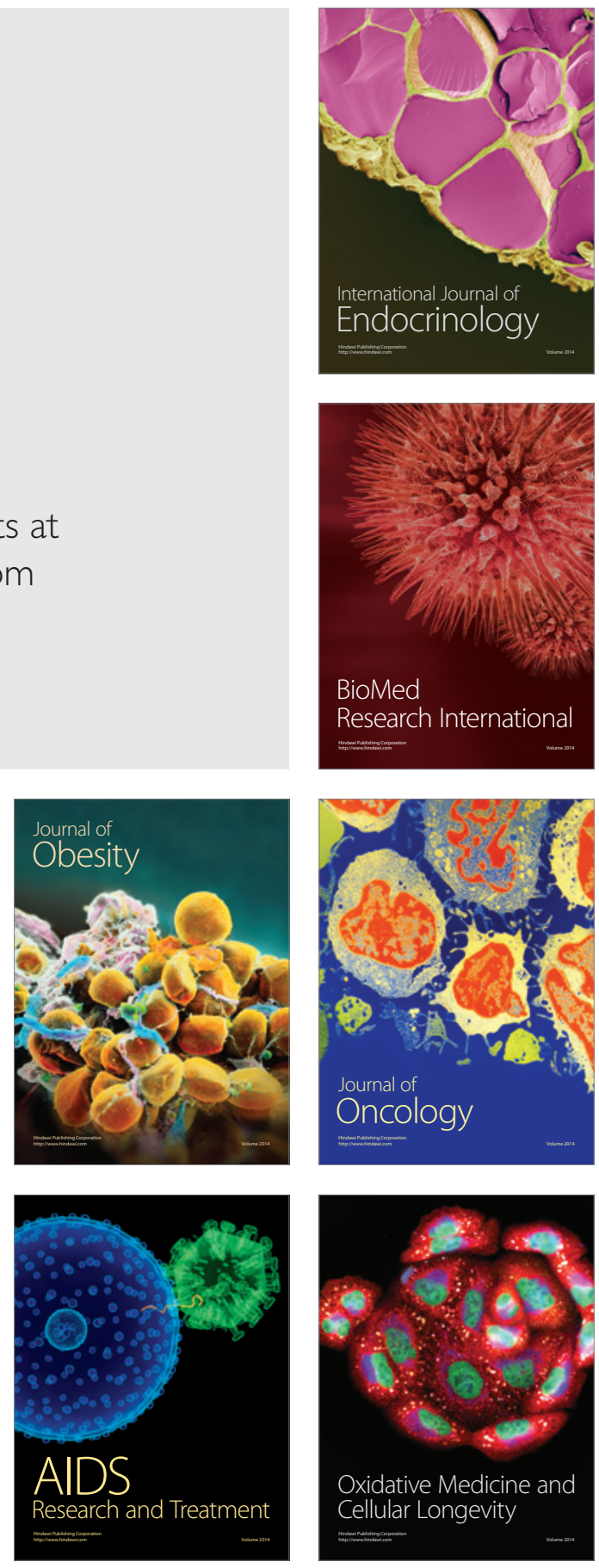